\title{
Heavy metal uptake by agro based waste materials
}

\author{
Suleman Qaiser* \\ Department of Chemical Engineering \\ University of Engineering and Technology \\ Post code 54890 \\ Lahore, Pakistan \\ Tel: 92426829488 \\ Fax: 92426822566 \\ E-mail: engrsqaiser@yahoo.com \\ Anwar R. Saleemi \\ Department of Chemical Engineering \\ University of Engineering and Technology \\ Post code 54890 \\ Lahore, Pakistan \\ Tel: 92426829288 \\ Fax: 92426822566 \\ E-mail: darsaleemi@yahoo.com

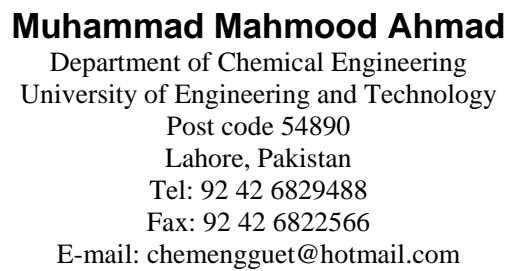

Financial support: Merit scholarship for PhD to Suleman Qaiser by Higher Education Commission Pakistan.

Keywords: biosorption, ficus religiosa leaves, hexavalent chromium, kinetics, lead, wastewater.

$\begin{array}{ll}\text { Abbreviations: } & \text { FTIR: fourier transform infrared } \\ & \mathrm{M}: \text { molarity } \\ & \mathrm{Pb}^{+2} \text { : lead cation } \\ \mathrm{rpm} \text { : rotations per minute }\end{array}$

Presence of heavy metals in the aquatic systems has become a serious problem. As a result, there has been a great deal of attention given to new technologies for removal of heavy metal ions from contaminated waters. Biosorption is one such emerging technology which utilized naturally occurring waste materials to sequester heavy metals from industrial wastewater. The aim of the present study was to utilize the locally available agricultural waste materials for heavy metal removal from industrial wastewater. The wastewater containing lead and hexavalent chromium was treated with biomass prepared from ficus religiosa leaves. It was fund that a time of one hr was sufficient for sorption to attain equilibrium. The equilibrium sorption capacity after one hr was $16.95 \pm 0.75 \mathrm{mg} \mathrm{g}^{-1}$ and $5.66 \pm 0.43 \mathrm{mg}$ $\mathrm{g}^{-1}$ for lead and chromium respectively. The optimum pH was 4 for lead and 1 for chromium. Temperature has strong influence on biosorption process. The removal of lead decreased with increase in temperature. On the other hand chromium removal increased with increase in temperature up to $40^{\circ} \mathrm{C}$ and then started decreasing. Ion exchange was the major removal mechanism along with physical sorption and precipitation. The biosorption data was well fitted to Langmuir adsorption model. The kinetics of biosorption process was well described by the pseudo $2^{\text {nd }}$ order kinetics model. It was concluded that adsorbent prepared from ficus religiosa leaves can be utilized for the treatment of heavy metals in wastewater.

The application of biosorption in environmental treatment has become a significant research area in the past ten years. Heavy metal ions are reported as priority pollutants, due to their mobility in natural water ecosystems and due to their toxicity (Volesky and Holan, 1995). The discharge of heavy metals into surface waters has become a matter of concern in Pakistan over the last two decades. These contaminants are introduced into surface waters through various industrial operations. The pollutants of concern include

*Corresponding author 
Table 1. Langmuir adsorption parameters for lead and chromium biosorption.

\begin{tabular}{|c|c|c|c|}
\hline Metal & $\begin{array}{c}\mathbf{q}_{\text {max }} \\
\left(\mathbf{m g ~ g}^{-\mathbf{1}}\right)\end{array}$ & $\mathbf{b}\left(\mathbf{I} \mathbf{~ m g}^{-\mathbf{1}}\right)$ & $\mathbf{R}^{\mathbf{2}}$ \\
\hline chromium & 26.25 & 0.012 & 0.996 \\
\hline lead & 37.45 & 0.022 & 0.972 \\
\hline
\end{tabular}

lead, chromium, zinc, and copper. Heavy metals such as zinc, lead and chromium have number of applications in basic engineering works, paper and pulp industries, leather tanning, petrochemicals fertilizers, etc. The hexavalent and trivalent chromium is often present in electroplating wastewater (Kratochvil et al. 1998). Other sources of chromium pollution are leather tanning, textile, metal processing, paint and pigments, dyeing and steel fabrication. Lead is used as industrial raw material in the manufacture of storage batteries, pigments, leaded glass, fuels, photographic materials, matches and explosives (Raji and Anirudhan, 1997).

Lead and chromium are toxic metal contaminants in water. According to Pakistan standards the maximum discharge limits for lead and chromium in wastewater are respectively $0.5 \mathrm{mg} \mathrm{l}^{-1}$ and $1.0 \mathrm{mg} \mathrm{l}^{-1}$. Maximum limit in drinking water is $0.05 \mathrm{mg} \mathrm{l}^{-1}$ for both metals. In fact there is no safe level of these metals in drinking water and even a very dilute content can cause adverse health effects. Lead is toxic to living organisms and if released into the environment can bio accumulate and enter the food chain. Lead is known to cause mental retardation, reduces haemoglobin production necessary for oxygen transport and it interferes with normal cellular metabolism. Lead has damaging effects on body nervous system. It reduces I.Q level in children. Strong exposure of hexavalent chromium causes cancer in the digestive tract and lungs and may cause gastric pain, nausea, vomiting, severe diarrhoea, and haemorrhage (Mohanty et al. 2005).

The conventional methods for treatment of lead and chromium wastes include: lime and soda ash precipitation,

Table 2. Values of constant separation factor for lead and chromium biosorption.

\begin{tabular}{|c|c|c|}
\hline $\begin{array}{c}\text { Initial } \\
\text { concentration } \\
\mathrm{C}_{0}, \mathrm{mg} \mathrm{l}^{-1}\end{array}$ & $\begin{array}{c}\text { (chromium) } \\
R_{L}=1 /(1+b C o)\end{array}$ & $\begin{array}{c}\text { (lead) } \\
R_{L}=1 /(1+b C o)\end{array}$ \\
\hline 10 & 0.895 & 0.819 \\
\hline 25 & 0.774 & 0.645 \\
\hline 50 & 0.631 & 0.476 \\
\hline 100 & 0.461 & 0.312 \\
\hline 250 & 0.255 & 0.154 \\
\hline 500 & 0.146 & 0.083 \\
\hline 1000 & 0.079 & 0.043 \\
\hline
\end{tabular}

adsorption with activated carbon, ion exchange, oxidation and reduction, fixation or cementation. These methods are economically unfavourable or technically complicated, and are used only in special cases of wastewater treatment (Kratochvil et al. 1998; Sharma, 2003).

Biosorption of heavy metals from aqueous solutions is a relatively new technology for the treatment of industrial wastewater. Adsorbent materials derived from low cost agricultural wastes can be used for the effective removal and recovery of heavy metal ions from wastewater streams. The major advantages of biosorption technology are its effectiveness in reducing the concentration of heavy metal ions to very low levels and the use of inexpensive biosorbent materials (Holan and Volesky, 1994; Kratochvil and Volesky, 1998).

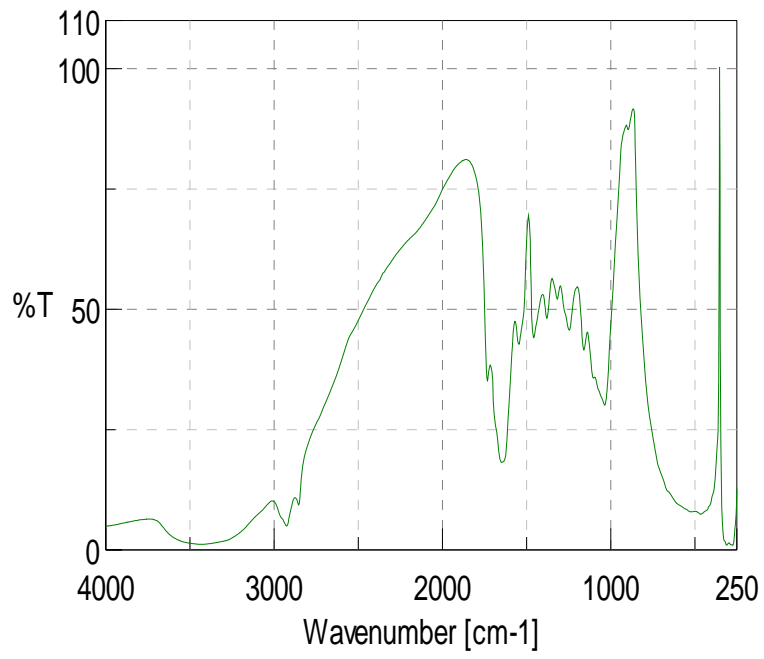

Figure 1. FTIR spectra of acid treated ficus religiosa leaves.

Removing metals from wastewater requires development of new sorbents. A wide range of commercial sorbents including chelating resins and activated carbon are available for metal sorption, but they are relatively expensive. In recent years, numerous low cost natural materials have been proposed as potential biosorbents. These include moss peat, algae, leaf mould, sea weeds, coconut husk, sago waste, peanut hull, hazelnut, bagasse, rice hull, sugar beet pulp, plants biomass and bituminous coal. (Lee and Volesky, 1997; Singh and Rawat, 1997; Gupta et al. 1998; Quek et al. 1998; Brown et al. 2000; Chong and Volesky, 2000; Dakiky et al. 2002; Johnson et al. 2002; Reddad et al. 2002; Babel and Kurniawan, 2003; Pagnanelli et al. 2003; Sekhar et al. 2003). In this research adsorbent prepared from ficus religiosa leaves was used for treatment of lead and chromium wastes. Effect of operating conditions like temperature, $\mathrm{pH}$ and initial metal concentration, on lead and chromium biosorption were investigated. 


\section{Composition of leaves}

Leaves of different trees are very versatile natured chemical species as these contain a variety of organic and inorganic compounds. Cellulose, hemicellulose, pectins and lignin present in the cell wall are the most important sorption sites (Volesky, 2003). Leaves have chlorophyll, carotene, anthocyanin and tannin which contribute to metal biosorption. The important feature of these compounds is that they contain hydroxyl, carboxylic, carbonyl, amino and nitro groups which are important sites for metal sorption (Volesky, 2003). Fourier transform infrared (FTIR) spectra of ficus religiosa leaves also indicated the presence of these functional groups (Figure 2).

$\mathrm{Cr}(\mathrm{VI})$ is present in solution as $\mathrm{CrO}_{4}^{-2}$ and $\mathrm{Cr}_{2} \mathrm{O}_{7}^{-2}$ at normal $\mathrm{pH}$ values but when $\mathrm{pH}$ values are reduced below 3 then Chromium exists in the form of $\mathrm{HCrO}_{4}^{-}$(Cimino et al. 2000; Demirbas et al. 2004; Park et al. 2006b). When adsorbent developed from ficus religiosa leaves is intimately mixed with chromium solution at low $\mathrm{pH}$ values then $\mathrm{OH}^{-}$group present in biomass are replaced by chromate ions in the solution. At $\mathrm{pH}$ values close to five the adsorbent surfaces are negatively charged due to release of $\mathrm{H}^{+}$ions, therefore these attract lead cation $\left(\mathrm{Pb}^{+2}\right)$. Leaves also have $\mathrm{Ca}, \mathrm{Mg}, \mathrm{Na}$ ions. These are present in the structure of complex organic compounds in leaves and exchange with $\mathrm{Pb}^{+2}$ cations during sorption process (Kratochvil et al. 1998). Leaves have considerable amounts of $\mathrm{CaO}, \mathrm{MgO}, \mathrm{Na}_{2} \mathrm{O}, \mathrm{K}_{2} \mathrm{O}$ etc. When leaf powder is mixed in water these oxides are converted into hydroxides. These hydroxides precipitate the metal cations (Schneider et al. 2001).

Table 3. Kinetics parameters for lead and chromium biosorption.

\begin{tabular}{|c|c|c|c|}
\hline Metal & $\begin{array}{c}\mathbf{k} \\
\left(\mathbf{g ~ m g}^{-1} \mathbf{m i n}^{-\mathbf{1}}\right)\end{array}$ & $\begin{array}{c}\mathbf{q}_{\mathrm{e}} \\
\left(\mathbf{m g ~ g}^{-\mathbf{1}}\right)\end{array}$ & $\mathbf{R}^{\mathbf{2}}$ \\
\hline chromium & 0.0436 & 5.86 & 0.998 \\
\hline lead & 0.0163 & 17.54 & 0.997 \\
\hline
\end{tabular}

\section{MATERIALS AND METHODS}

\section{Chemicals and instruments}

All chemicals used were of analytical reagent grade. Lead solution of $1000 \mathrm{mg} \mathrm{l}^{-1}$ concentration was prepared by dissolving $1.6 \mathrm{~g}$ lead nitrate in one litre distilled water. Hexavalent chromium solution of $1000 \mathrm{mg} \mathrm{l}^{-1}$ concentration was prepared by dissolving $2.827 \mathrm{~g}$ potassium dichromate in one litre distilled water. These solutions were further diluted to get solutions of various known concentrations of lead and chromium. A variable speed shaker 20-500 rotations per minute (rpm) was used for batch experimentation. It has the capacity of holding eight Erlenmeyer flasks simultaneously. It was equipped with

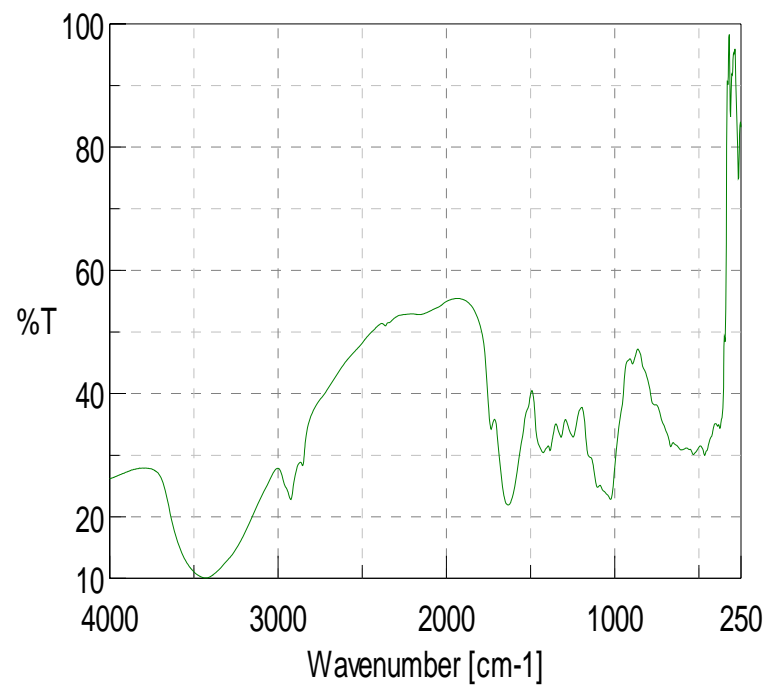

Figure 2. FTIR spectra of un-treated ficus religiosa leaves.

heating water bath. A vacuum filter assembly having Pyrex filter funnel of porosity grade 4 was used for separating adsorbent from solution. The unknown quantities of lead and chromium were determined by Shimadzu 6800 atomic absorption spectrophotometer using an air-acetylene flame. The adsorbent was analyzed by JASCO FTIR 4000 spectrometer.

\section{Biomass preparation}

Ficus religiosa leaves were collected from local environment of University of Engineering and Technology Lahore, Pakistan. These leaves were washed with tap water and dried in shadow. Dried leaves were ground and sieved to 50 mesh sizes. This powder was soaked in 0.1 molarity (M) $\mathrm{HNO}_{3}$ for $24 \mathrm{hrs}$ (50 g leaves powder was soaked per

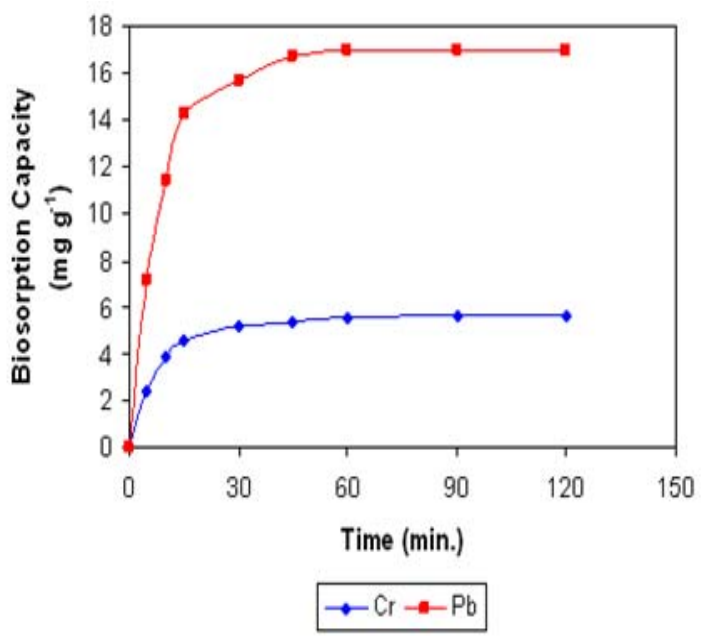

Figure 3. Equilibrium time for lead and chromium biosorption. 


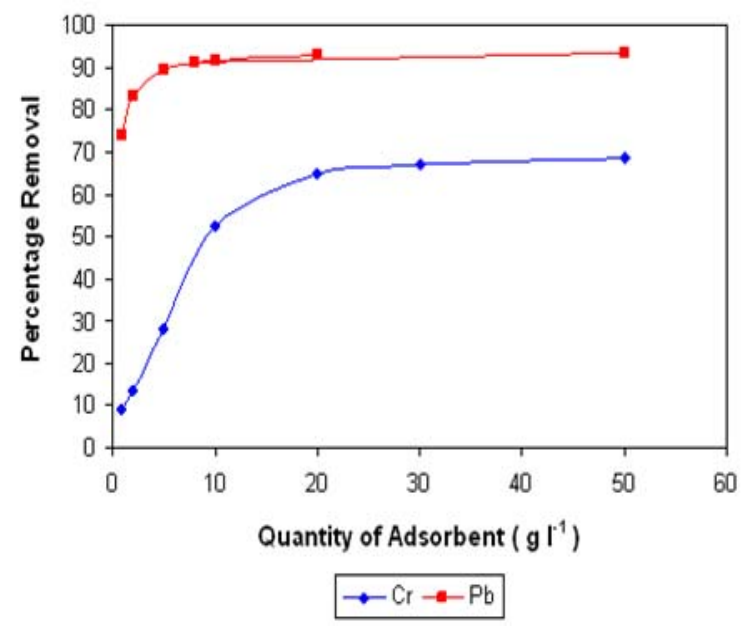

Figure 4. Effect of adsorbent dose on percentage removal of lead and chromium.

litre). It was filtered and washed with distilled water to remove acid contents. The washing was continued till the $\mathrm{pH}$ of the filtrate became near neutral. It was first dried at room temperature and then in an oven at $105^{\circ} \mathrm{C}$ to remove moisture. This biomass was stored in air tight glass bottles to protect it from humidity.

\section{Fourier transform infrared analysis}

FTIR spectroscopy was used to identify the chemical groups present in leaves. The samples were examined using JASCO FTIR 4000 spectrometer within range 400-4000 $\mathrm{cm}^{-1}$. $\mathrm{KBr}$ was used as background material in all the analysis. $0.0035 \mathrm{~g}$ leaves powder was mixed with $0.5 \mathrm{~g} \mathrm{KBr}$ and pressed to form a pellet. FTIR spectra of leaves indicated the presence of hydroxyl, carboxyl, carbonyl, amino and nitro groups which are important sorption sites. There were also indications of presence of heavy metals and inorganic compounds below $870 \mathrm{~cm}^{-1}$. These metals were removed by treatment of leaves with nitric acid to improve the sorption capacity. FTIR spectra of acid treated ficus religiosa leaves and untreated ficus religiosa leaves are shown in Figure 1 and Figure 2 respectively.

\section{RESULTS AND DISCUSSION}

\section{Determination of equilibrium time}

Batch experiments were carried out to find the equilibrium time for sorption of chromium and lead on ficus religiosa leaves. All experiments were performed three times and average values were used in all calculations. $1.0 \mathrm{~g}$ ficus religiosa leaves powder of 50 mesh sizes was mixed in 100 $\mathrm{ml}$ solutions of lead and chromium. The initial concentration of each solution was $100 \mathrm{mg} \mathrm{l}^{-1}$. It was shaken at $200 \mathrm{rpm}$ and samples were collected at different time intervals. The $\mathrm{pH}$ for the experiment was taken as original $\mathrm{pH}$ of solutions which was 5.2 for chromium and 5.8 for lead. After completion of each batch of experiments the solution was filtered using vacuum filter assembly. Filtrate was analyzed using atomic absorption spectrophotometer to determine the amount of metal left after sorption. The amount of metal sorbed was calculated by material balance. Sorption capacity $\mathrm{q}$ was determined using the formula:

$$
q=\frac{V\left(C_{0}-C_{f}\right)}{m}
$$

Where $\mathrm{C}_{0}$ and $\mathrm{C}_{\mathrm{f}}$ are the initial and final concentrations of metal in solution, $\mathrm{V}$ is the volume of solution and $\mathrm{m}$ is the mass of adsorbent. As shown in Figure 3 about 80\% removal was attained in first $15 \mathrm{~min}$ and concentration became almost constant after $45 \mathrm{~min}$. The fast initial uptake was due to the accumulation of metal ions on surface of adsorbent which is a rapid step. More time was consumed on diffusion of ions to binding sites. It was concluded that one hr was sufficient for sorption to attain equilibrium. The equilibrium capacity obtained after one hr of sorption was $5.66 \pm 0.43 \mathrm{mg} \mathrm{g}^{-1}$ and $16.95 \pm 0.75 \mathrm{mg} \mathrm{g}^{-1}$ for chromium and lead respectively.

\section{Effect of adsorbent dose}

Keeping all other parameters constant adsorbent dose was varied from 1.0 to $50 \mathrm{gm} \mathrm{l}^{-1}$. It can be seen from Figure 4 that an adsorbent dose of $10 \mathrm{gm} \mathrm{l}^{-1}$ is sufficient for optimal removal of both metals. Increasing the dose further did not affect the percentage removal. The removal capacity was low at high dose rate and vice versa. This was due to metal concentration shortage in solution at high dose rates.

\section{Effect of pH}

Keeping the same operating conditions as mentioned previously, $\mathrm{pH}$ of solution was varied from 0.5 to 8 by the

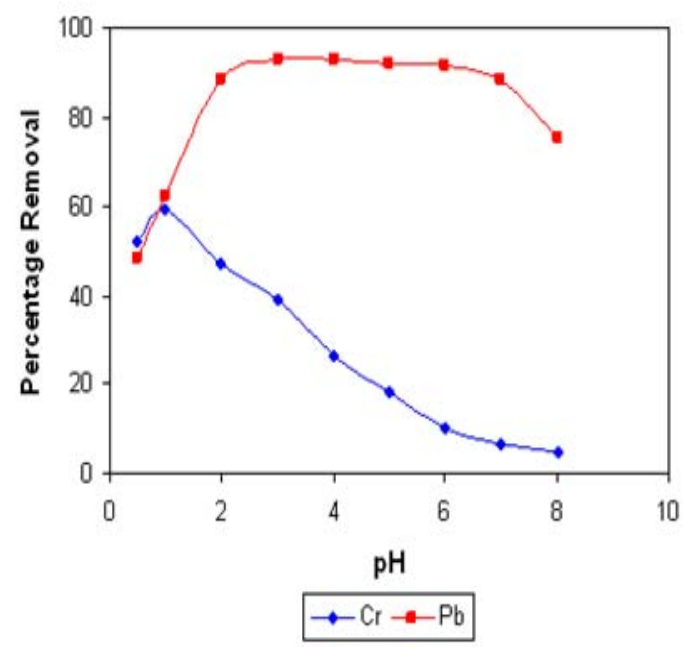

Figure 5. Effect of pH on percentage removal of lead and chromium. 


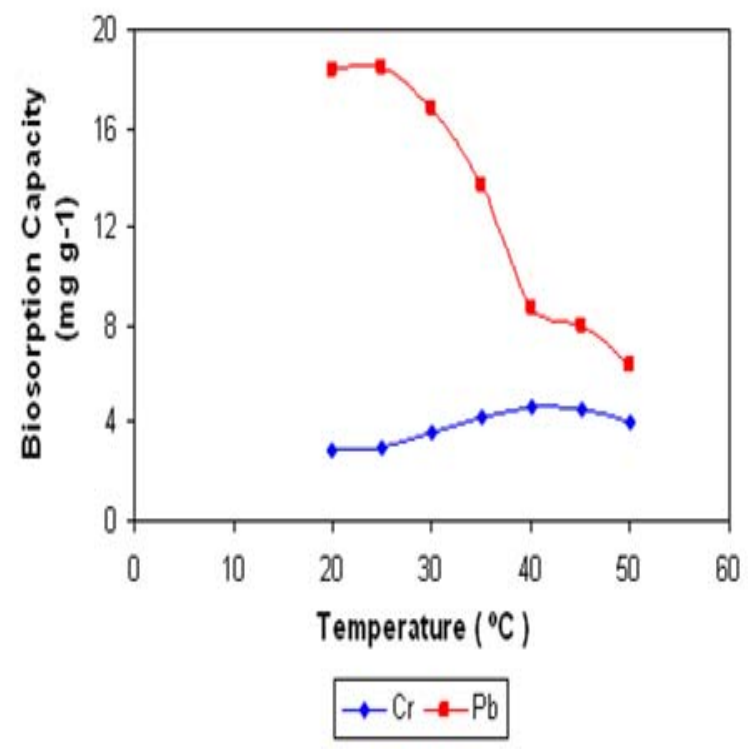

Figure 6. Effect of temperature on biosorption capacity of lead and chromium

addition of $0.1 \mathrm{M}$ nitric acid and $0.1 \mathrm{M}$ ammonia solution. It was found that sorption of chromium was more at low $\mathrm{pH}$ where as lead has almost same sorption in the $\mathrm{pH}$ range of 3 to 5 (Figure 5). The optimal $\mathrm{pH}$ for lead and chromium was 4 and 1 respectively. At pH higher than 6 both metals were precipitated due to formation of hydroxides and removal due to sorption was very low. At low $\mathrm{pH}$ the concentration of proton was high and metal binding sites became positively charged repelling the $\mathrm{Pb}^{+2}$ cations and attracting the anions like $\mathrm{HCrO}_{4}^{-}$and $\mathrm{CrO}_{4}^{-2}$. Thus at low $\mathrm{pH}$ removal of lead was low and removal of hexavalent chromium was high. Also more chromium removal at low $\mathrm{pH}$ was due to the reduction of $\mathrm{Cr}(\mathrm{VI})$ to $\mathrm{Cr}$ (III) (Park et al. 2006a), which was then precipitated at the biomass surface by forming $\mathrm{Cr}(\mathrm{OH})_{3}$. In this reduction $\mathrm{H}^{+}$was consumed and increase in $\mathrm{pH}$ was observed at the end of experiments. The reduction of $\mathrm{Cr}(\mathrm{VI})$ to $\mathrm{Cr}(\mathrm{III})$ was confirmed by analyzing the solution for $\operatorname{Cr}(\mathrm{VI})$ using 1,5 diphenylcarbazide in spectrophotometer. At $\mathrm{pH}$ close to 5 the binding sites became negatively charged due to presence of hydroxyl,

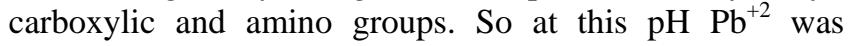
attracted by the adsorbent. A decrease in $\mathrm{pH}$ was observed at the end of experiments in case of lead sorption. This was due to the release of proton as result of ion exchange between $\mathrm{Pb}^{+2}$ and $\mathrm{H}^{+}$ions. In case of hexavalent chromium there was an increase in $\mathrm{pH}$ which was due to exchange of $\mathrm{HCrO}_{4}{ }^{-}$with $\mathrm{OH}^{-}$.

\section{Effect of temperature}

Keeping all other parameters constant temperature was varied from $20^{\circ} \mathrm{C}$ to $50^{\circ} \mathrm{C}$. The sorption of chromium increased slightly with the increase in temperature up to $40^{\circ} \mathrm{C}$ and then started decreasing, where as uptake of lead decreased considerably with increase in temperature from $30^{\circ} \mathrm{C}$ to $50^{\circ} \mathrm{C}$ (Figure 6). The temperature higher than $40^{\circ} \mathrm{C}$ caused a change in the texture of the biomass and thus reduced its sorption capacity.

Biomass contains more than one type of sites for metal binding. The effect of temperature on each site is different and contributes to overall metal uptake. The effect of temperature on biosorption also depends on the heat of sorption. Usually for physical sorption heat of sorption is negative; sorption reaction is exothermic and preferred at lower temperature. For chemisorption the overall heat of sorption is combination of heat of various reactions taking place at sorption sites. It depends on type of metal and adsorbent. That is the reason for having different behaviour of lead and chromium uptake with temperature.

\section{Effect of initial metal concentration}

Initial concentrations of both metals were varied from 10 to $1000 \mathrm{mg} \mathrm{l}^{-1}$ and quantity of adsorbent was kept constant at $10 \mathrm{gm} \mathrm{l}^{-1}$. It was observed that removal capacity decreased with decrease in metal concentration.

Langmuir adsorption model was applied to data:

$$
\mathrm{q}_{e}=\mathrm{q}_{\max } \frac{\mathrm{b} \mathrm{C}_{\mathrm{e}}}{1+\mathrm{bC}_{\mathrm{e}}}
$$

This equation was rearranged to get:

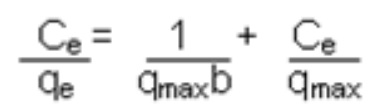

Where $\mathrm{q}_{\mathrm{e}}$ is the amount of metal sorbed per unit weight of biomass at equilibrium, $\mathrm{C}_{\mathrm{e}}$ is the residual equilibrium metal

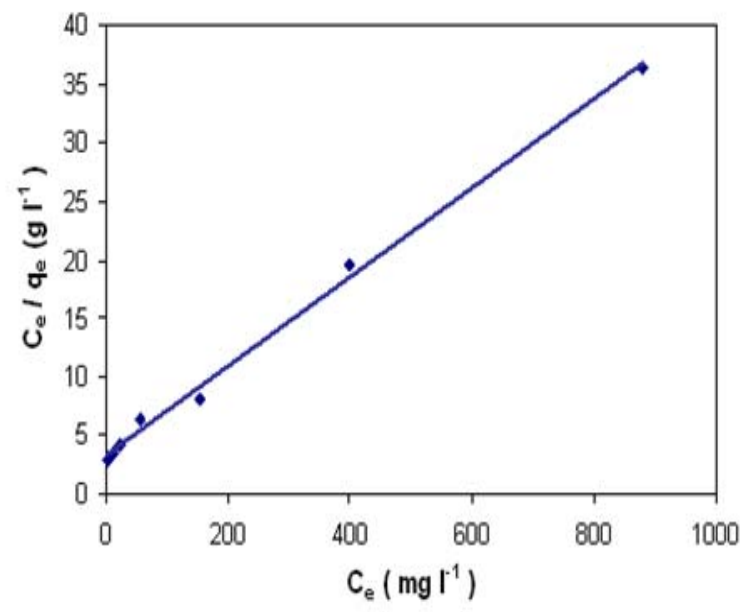

Figure 7. Langmuir plot for hexavalent chromium biosorption. 


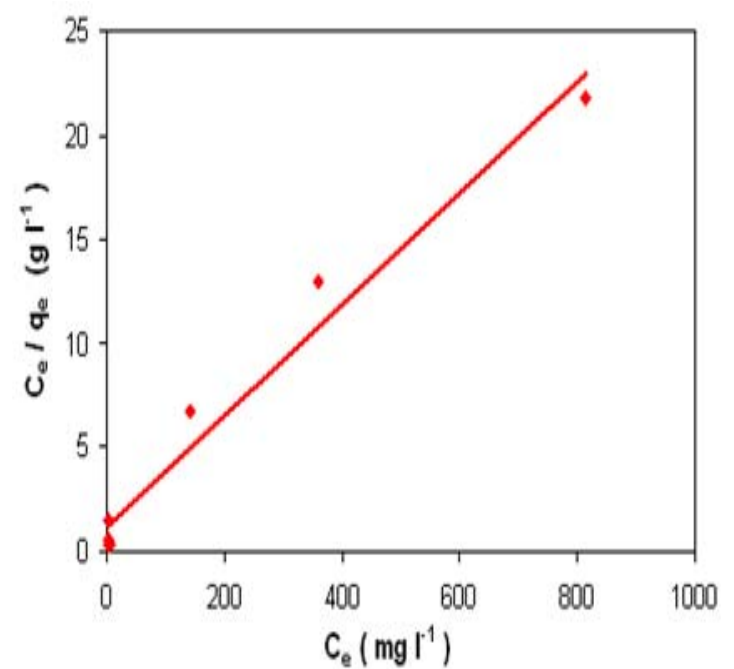

Figure 8. Langmuir plot for lead biosorption.

concentration left in solution after binding, $\mathrm{q}_{\max }$ is the maximum possible amount of metal ion adsorbed per unit weight of biomass and $b$ is the equilibrium constant related to the affinity of the binding sites for the metals, lower is $b$ more is the affinity of metal to biomass.

Equilibrium concentration $\mathrm{C}_{\mathrm{e}}$ and equilibrium capacity $\mathrm{q}_{\mathrm{e}}$ were calculated for each initial metal concentration. $\mathrm{C}_{e}$ was plotted against $\mathrm{C}_{\mathrm{e}} / \mathrm{q}_{\mathrm{e}}$ and a straight line was fitted in the data. Correlation coefficient of 0.996 for chromium and 0.972 for lead indicate that sorption followed Langmuir model (Figure 7 and Figure 8). Values of Langmuir constants $\mathrm{q}_{\max }$ and $\mathrm{b}$ were calculated from slope and intercept of lines in Figure 7 and Figure 8 and are shown in Table 1.

Low values of parameter $b$ indicate that ficus religiosa leaves have high affinity for chromium and lead. The values of equilibrium relation parameter, $R_{L}$ were calculated for various initial concentrations for both metals. As shown in Table 2, $\mathrm{R}_{\mathrm{L}}$ values lie between 0 and 1 which indicate favourable sorption isotherm for both metals.

\section{Biosorption kinetics}

In order to explain the kinetics of biosorption pseudo second order kinetics model was applied.

$$
\frac{d q_{t}}{d t}=k\left(q_{e}-q_{t}\right)^{2}
$$

This equation was integrated and arranged to get the following equation.

$$
\frac{t}{q_{t}}=\frac{1}{k q_{e}^{2}}+\frac{1}{q_{e}} t
$$

Where $\mathrm{k}$ is the sorption coefficient, $\mathrm{q}_{\mathrm{e}}$ is the equilibrium capacity and $\mathrm{q}_{\mathrm{t}}$ is the sorption capacity at any time $\mathrm{t}$.

Time, $\mathrm{t}$ was plotted against $\mathrm{t} / \mathrm{q}_{\mathrm{t}}$ and straight lines having correlation coefficient of 0.99 were fitted in the data for both metals. The sorption coefficient $\mathrm{k}$ and equilibrium capacity $\mathrm{q}_{\mathrm{e}}$ were calculated from the slope and intercept of lines in Figure 9 and are shown in Table 3.

The values obtained for equilibrium capacity for both metals were very close to those obtained experimentally after one hr of sorption. It confirmed that one hr was sufficient for sorption to attain equilibrium and sorption followed pseudo $2^{\text {nd }}$ order kinetics

\section{CONCLUDING REMARKS}

Ficus religiosa leaves powder was found to be a very good adsorbent for hexavalent chromium and lead. It has good sorption capacity for both metals. The sorption capacity for hexavalent chromium was $5.66 \pm 0.43 \mathrm{mg} \mathrm{g}^{-1}$ and for lead was $16.95 \pm 0.75 \mathrm{mg} \mathrm{g}^{-1}$. The sorption was $\mathrm{pH}$ dependent and optimal $\mathrm{pH}$ was 4 and 1 for lead and chromium respectively. Biosorption of metals was temperature dependent. Optimal temperature was $40^{\circ} \mathrm{C}$ for chromim and $25^{\circ} \mathrm{C}$ for lead. Main removal mechanism was ion exchange between protons and metal cations in case of lead and between metal anions and hydroxyl ions in case of hexavalent chromium. This fact is indicated by the change

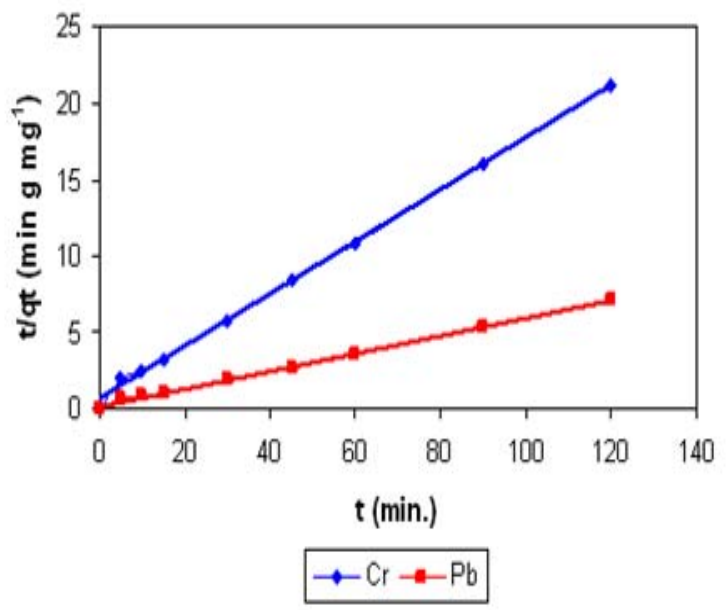

Figure 9. Kinetics of lead and chromium biosorption. 
of $\mathrm{pH}$ at the end of biosorption process. Physical sorption and precipitation also contributed to removal of metals. The biosorption process followed Langmuir model for both metals which indicated that ion exchange took place in a monolayer at the surface of adsorbent. The kinetics of biosorption process was represented well by pseudo $2^{\text {nd }}$ order kinetics model.

\section{ACKNOWLEDGMENTS}

First author is thankful to Dr. Shaiq A Haq for his valuable suggestions. Special thanks to Dr. Nadeem Feroz and Muhammad Umar for their cooperation and support.

\section{REFERENCES}

BABEL, Sandhya and KURNIAWAN, Tonni Agustiono. Low-cost adsorbents for heavy metals uptake from contaminated water: a review. Journal of Hazardous Materials, February 2003, vol. 97, no. 1-3, p.219-243.

BROWN, Pauline; JEFCOAT, I. Atly; PARRISH, Dana; GILL, Sarah and GRAHAM, Elizabeth. Evaluation of the adsorptive capacity of peanut hull pellets for heavy metals in solution. Advances in Environmental Research, June 2000, vol. 4, no. 1, p. 19-29.

CIMINO, Giuseppe; PASSERINI, Amedeo and TOSCANO, Giovanni. Removal of toxic cations and Cr(VI) from aqueous solution by hazelnut shell. Water Research, August 2000, vol. 34, no. 11, p. 2955-2962.

CHONG, K.H. and VOLESKY, B. Metal biosorption equilibria in a ternary system. Biotechnology and Bioengineering, March 2000, vol. 49, no. 6, p. 629-638.

DAKIKY, M.; KHAMIS, M.; MANASSRA, A. and MER'EB, M. Selective adsorption of Cr(VI) in industrial wastewater using low-cost abundantly available adsorbents. Advances in Environmental Research, October 2002, vol. 6, no. 4, p. 533-540.

DEMIRBAS, Erhan; KOBYA, Mehmet; SENTURK, Elif and OZKAN, Tuncay. Adsorption kinetics for the removal of chromium (VI) from aqueous solutions on the activated carbons prepared from agricultural wastes. Water $S A$, October 2004, vol. 30, no. 4, p. 533-539.

GUPTA, V.K.; MOHAN, D. and SHARMA, S. Removal of lead from wastewater using bagasse fly ash-a sugar industry waste material. Separation Science and Technology, June 1998, vol. 33, no. 9, p. 1331-1343.

HOLAN, Z.R. and VOLESKY, B. Biosorption of lead and nickel by biomass of marine algae. Biotechnology and Bioengineering, May 1994, vol. 43, no. 11, p. 1001-1009.
JOHNSON, P.D.; WATSON, M.A.; BROWN, J. and JEFCOAT, I.A. Peanut hull pellets as a single use sorbent for the capture of $\mathrm{Cu}(\mathrm{II})$ from wastewater. Waste Management, August 2002, vol. 22, no. 5, p. 471-480.

KRATOCHVIL, David and VOLESKY, Bohumil. Advances in the biosorption of heavy metals. Trends in Biotechnology, July 1998, vol. 16, no. 7, p. 291-300.

KRATOCHVIL, David; PIMENTEL, Patricia and VOLESKY, Bohumil. Removal of trivalent and hexavalent chromium by seaweed biosorbent. Environmental Science and Technology, September 1998, vol. 32, no. 18, p. 26932698.

LEE, Hak Sung and VOLESKY, Bohumil. Interaction of light metals and protons with seaweed biosorbent. Water Research, December 1997, vol. 31, no. 12, p. 3082-3088.

MOHANTY, K.; JHA, M.; BISWAS, M.N. and MEIKAP, B.C. Removal of chromium (VI) from dilute aqueous solutions by activated carbon developed from Terminalia arjuna nuts activated with zinc chloride. Chemical Engineering Science, June 2005, vol. 60, no. 11, p. 30493059.

PAGNANELLI, Francesca; MAINELLI, Sara; VEGLIO, Francesco and TORO, Luigi. Heavy metal removal by olive pomace: biosorbent characterization and equilibrium modeling. Chemical Engineering Science, October 2003, vol. 58, no. 20, p. 4709-4717.

PARK, Donghee; YUN, Yeoung-Sang; JO, Ji Hye and PARK, Jong Moon. Biosorption process for treatment of electroplating wastewater containing $\mathrm{Cr}(\mathrm{VI})$ : Laboratoryscale feasibility test. Industrial and Engineering Chemistry Research, July 2006a, vol. 45, no. 14, p. 5059-5065.

PARK, D.; YUN, Y.-S.; LIM, S.-R. and PARK, J.M. Kinetic analysis and mathematical modeling of $\mathrm{Cr}(\mathrm{VI})$ removal in a differential reactor packed with ecklonia biomass. Journal of Microbiology and Biotechnology, November 2006b, vol. 16, no. 11, p. 1720-1727.

QUEK, S.Y.; WASE, D.A.J. and FORSTER, C.F. The use of sago waste for the sorption of lead and copper. Water SA, July 1998, vol. 24, no. 3, p. 251-256.

REDDAD, Zacaria; GERENTE, Claire; ANDRES, Yves and LE CLOIREC, Pierre. Adsorption of several metal ions onto a low-cost biosorbent: Kinetic and equilibrium studies. Environmental Science and Technology, May 2002, vol. 36, no. 9, p. 2067-2073.

RAJI, C. and ANIRUDHAN, T.S. Chromium (VI) adsorption by sawdust carbon: kinetics and equilibrium. 
Qaiser, S. et al.

Indian Journal of Chemical Technology, September 1997, vol. 4, no. 5, p. 228-236.

SCHNEIDER, Ivo A.H.; RUBIO, Jorge and SMITH, Ross $\mathrm{W}$. Biosorption of metals onto plant biomass: exchange adsorption or surface precipitation? International Journal of Mineral Processing, May 2001, vol. 62, no. 1-4, p. 111120.

SEKHAR, K.C.; KAMALA, C.T.; CHARY, N.S. and ANJANEYULU, Y. Removal of heavy metals using a plant biomass with reference to environmental control. International Journal of Mineral Processing, January 2003, vol. 68, no. 1-4, p. 37-45.

SHARMA, Y.C. Cr(VI) removal from industrial effluents by adsorption on an indigenous low-cost material. Colloids and Surfaces A: Physicochemical and Engineering Aspects, March 2003, vol. 215, no. 1-3, p. 155-162.

SINGH, D. and RAWAT, N.S. Adsorption of heavy metals on treated and untreated low grade bituminous coal. Indian Journal of Chemical Technology, January 1997, vol. 4, no. 1, p. 39-41.

VOLESKY, B. and HOLAN, Z.R. Biosorption of heavy metals. Biotechnology Progress, May-June 1995, vol. 11, no. 3, p. 235-250.

VOLESKY, B. Sorption and Biosorption. Montreal-St. Lambert, Quebec, Canada, BV Sorbex Inc., 2003. 316 p. ISBN 0-9732983-0-8. 